Cellular Physiology
and Biochemistry and Biochemistry Pullished online: November 26, 2015

Accepted: October 22, 2015

This article is licensed under the Cre tional License (CC BY-NC-ND) Creative Commons Attribution-NonCommercial-NoDerivatives 4.0 International License (CC BY-NC-ND) (http://www.karger.com/Services/OpenAccessLicense). Usage and distributio for commercial purposes as well as any distribution of modified material requires written permission.

Review

\title{
Multiple Roles of MicroRNA-100 in Human Cancer and its Therapeutic Potential
}

\author{
Chen Li Yanping Gao Kai Zhang Jing Chen Siqi Han Bing Feng Rui Wang \\ Longbang Chen
}

Department of Medical Oncology, Jinling Hospital, School of Medicine, Nanjing University, Nanjing, China

\section{Key Words}

MiR-100 • Biogenesis • Cellular pathways • Tumor suppressor • Tumor promoter

\begin{abstract}
MicroRNAs (miRNAs) are a recently discovered class of endogenous, small (about 22 nucleotides) non-coding RNAs, which play important roles in cancer development and progression. Emerging evidence shows that microRNAs exert their regulatory effects by directly binding to the $3^{\prime}$ - untranslated regions (UTRs) of their target genes. MicroRNA-100 (miR-100) is aberrantly expressed and functions in many human cancers by regulating multiple cell processes, such as cell cycle, proliferation, differentiation, migration, invasion and apoptosis, via post-transcriptionally regulating various target genes. A better understanding of the molecular mechanisms involved in miR-100-mediated tumor progression will provide an opportunity for exploring novel miR-100-based targeted therapies for human cancers. This review aims to summarize the recently published literature on the roles of miR-100 in regulating tumorigenesis, and explore its potential clinical applications for cancer diagnosis, prognosis and clinical treatment.

\section{Introduction}

As the most studied non-coding RNAs, miRNAs are short (about 22 nucleotides) endogenous non-coding RNAs, which regulate gene expression at a posttranscriptional level to promote mRNA degradation and repress translation by binding to the 3'-UTR of targets [1, 2]. Studies demonstrate that more than $50 \%$ of the miRNAs are located in so-called "fragile sites" on chromosomes which are frequently deleted, amplified, or rearranged to involve cancers [3]. Since their discovery in 1993, aberrant expression patterns and functional abnormalities of miRNA expressions have been identified to be associated with a variety of 
human diseases, including cancers [4, 5]. MiRNAs play vital roles in the regulation of almost every cellular process, including proliferation, apoptosis, differentiation and angiogenesis. Considering their implications in multiple biological processes, current research of miRNAs is mainly focused on clarifying their physiological and pathological functions, exploring potential miRNAs target genes, as well as deciphering the molecular mechanism underlying transcriptional regulation of miRNAs.

Comparative studies indicate that the origin of miR-100 which is a member of the miR99 family could date back to the bilaterian ancestor [6]. The expression patterns and effects of miR-100 in tumor progression have not been fully elucidated, and the recent studies have shown controversial results [7, 8]. In human cancers, miR-100 has been reported to function as either a oncogenic miRNA or a tumor suppressive miRNA, which depends on tumor types and microenviroment [9]. Many studies have revealed that miR-100 functions in numerous important biological processes such as metabolism, cell cycle, migration, epithelialmesenchymal transition (EMT), differentiation and cell survival. Moreover, dysregulation of miR-100 is associated with a poor prognosis for different cancers, indicating that miR-100 may be a good candidate for using as a prognostic biomarker and a potential therapeutic target for human cancers. This review aims to summarize recent research on the target genes of miR-100 and its roles in regulating tumorigenesis as well as its implication for clinical therapy.

\section{Dysregulation of miR-100 in many human cancers}

The miR-100 gene is located on chromosome 11 at 11q24.1 (Gene ID: 406892) [10]. A unique biogenesis pathway including at least 4 steps produces mature miRNA, including miR-100 [11] (Fig. 1). The first step in miRNA biogenesis is the formation of a long primary miRNA (pri-miRNA) with a 5'm7G cap and a 3' poly-A tail, which is initially transcribed by RNA Polymerase II in the nucleus [12]. Secondly, the pri-miR-100 is cropped into a 65nt stem-loop structure by a nuclear protein complex consisting of the nuclear RNase III enzyme Drosha, the double-stranded RNA binding protein Pasha / DiGeorge Critical Region 8 (DGCR8) and multiple RNA-associated proteins $[13,14]$. This cleavage event is important for the necessity that it predetermines mature miRNA sequence and lays a foundation for the subsequent events [15]. Thirdly, after nuclear processing, the pre-miR-100 is exported into the cytoplasm with the help of the nuclear export factor Exportin 5 (Expo5) $[16,17]$. Here, a second RNase III enzyme termed Dicer, subsequently removes the loop region of the pre-miRNA to produce a $\sim 22 \mathrm{bp}$ double-stranded RNA duplex [16]. One strand of this short-lived duplex is degraded by an unknown nuclease, while the other strand with the less stable 5 '-end remains as a mature miRNA $[15,18]$. Finally, the miR-100 strand of the duplex is incorporated into a large protein complex, termed the RNA induced silencing complex (RISC), where miR-100 guides RISC to bind with 3'-UTR of the target gene mRNA, thereby functions to inhibit protein translation and/or promote mRNA degradation [10, 19].

Recently, dysregulation of miR-100 has been reported to be involved in tumor occurrence, development, and drug resistance [20] (Table 1). Some highly expressed miRNAs act as oncogenes by repressing tumor suppressors, whereas low-level miRNAs act as tumor suppressors by negatively regulating oncogenes. One hand, down-regulation of miR-100 has been reported in a variety of human tumors, such as head and neck squamous cell carcinoma (HNSCC) [21-23], nasopharyngeal cancer (NPC) [24], oral squamous cell carcinoma (OSCC ) [25], esophageal squamous cell carcinoma (ESCC) [26-31], breast cancer[32-34], non-small cell lung cancer (NSCLC) [35, 36], gastric cancer (GC) [8], hepatocellular carcinoma (HCC) [3741], pancreatic adenocarcinoma [42-44], adrenocortical cancer [45], bladder cancer [46-55], ovarian cancer [56-60], endometrioid endometrial carcinoma (EEC) [61], cervical cancer [62, 63], small cell carcinoma of the cervix (SCCC) [64], prostate cancer (PC) [65-70], colorectal cancer (CRC) [71-73], chondrosarcomas [74], osteosarcoma [75, 76], glioblastoma (GBM) [77], acute lymphoblastic leukemia (ALL) [78-81], and on the other hand, overexpression 
Fig. 1. MiRNA biogenesis. Drosha together with Pasha/DGCR8 cuts pri-miRNA to form the stem-loop structural pre-miRNA, and then Dicer removes the loop region from pre-miRNA, leaving the mature sequence miRNA.

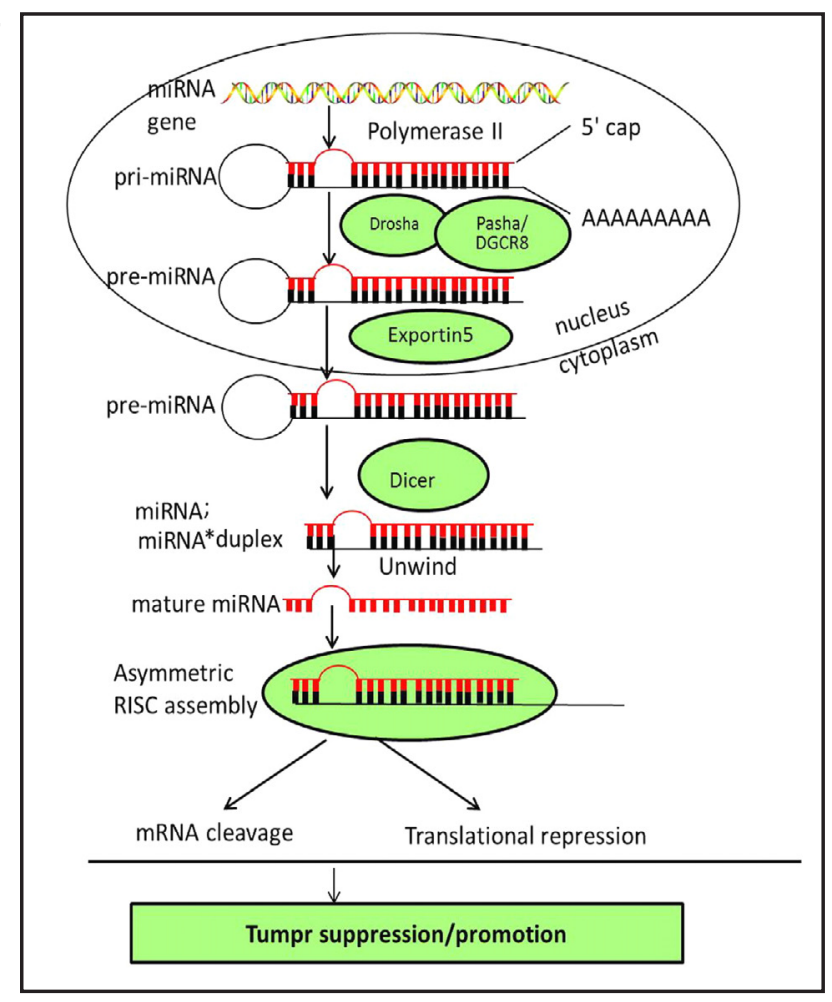

Table 1. Dysregulation of miR-100 in different human cancers

\begin{tabular}{|c|c|c|c|c|}
\hline Cancer type & MiR-100 expression & Sample & Main Target gene & References \\
\hline Gastric cancer & Up regulation & $\begin{array}{l}\text { Cell lines } \\
\text { serum } \\
\text { Tissues } \\
\text { Tissues }\end{array}$ & HS3ST2 & $\begin{array}{l}{[7]} \\
{[9]} \\
{[85]} \\
{[8]}\end{array}$ \\
\hline $\begin{array}{l}\text { Head and neck squamous cell } \\
\text { carcinoma (HNSCC) }\end{array}$ & Down regulation & Tissues & IGF1R/mTOR & [21-23] \\
\hline Nasopharyngeal cancer (NPC) & Down regulation & Cell lines & PIK1 & {$[24]$} \\
\hline $\begin{array}{l}\text { Oral squamous cell carcinoma } \\
\text { (OSCC) }\end{array}$ & Down regulation & Cell lines & FGFR3 & {$[25]$} \\
\hline $\begin{array}{l}\text { Esophageal squamous cell } \\
\text { carcinoma (ESCC) }\end{array}$ & Down regulation & Tissues & mTOR & $\begin{array}{l}{[26,27,30,} \\
31]\end{array}$ \\
\hline & Up regulation & Serum & & {$[28,29]$} \\
\hline Breast cancer & Down regulation & $\begin{array}{l}\text { Cell lines } \\
\text { Tissues }\end{array}$ & $\begin{array}{l}\text { PIK1,Wnt/ } \beta \text {-catenin, } \\
\text { IGF2,SMARCA5 ,HOXA1, EphB6 }\end{array}$ & $\begin{array}{l}{[33,34]} \\
{[32]}\end{array}$ \\
\hline $\begin{array}{l}\text { Non-small cell lung cancer } \\
\text { (NSCLC), }\end{array}$ & $\begin{array}{l}\text { Down regulation } \\
\text { Up regulation }\end{array}$ & $\begin{array}{l}\text { Cell lines } \\
\text { Tissues } \\
\text { Pleural effusion }\end{array}$ & PLK1 & $\begin{array}{l}{[35]} \\
{[36,84]} \\
{[83]}\end{array}$ \\
\hline Hepatocellular carcinoma (HCC) & $\begin{array}{l}\text { Down regulation } \\
\text { Up regulation }\end{array}$ & $\begin{array}{l}\text { Tissues } \\
\text { Serum }\end{array}$ & ICMT-Rac1,PLk1,mTOR ,IGF-1R & $\begin{array}{l}{[37-41]} \\
{[86]}\end{array}$ \\
\hline Pancreatic adenocarcinoma & Up regulation & $\begin{array}{l}\text { Tissues/ } \\
\text { Metastatic cell lines }\end{array}$ & IGF1-R, FGFR3 & [87-89] \\
\hline & Down regulation & Cell lines, stem cell, serum & & [42-44] \\
\hline Adrenocortical cancer & Down regulation & Tissues & IGF - mTOR & {$[45]$} \\
\hline Bladder cancer & Down regulation & Tissues & FGFR3,mTOR, & [46-55] \\
\hline Ovarian cancer & Down regulation & Tissues & PLK1,FRAP1/mTOR & {$[56-60]$} \\
\hline $\begin{array}{l}\text { Endometrioid end ometrial } \\
\text { carcinoma }\end{array}$ & Down regulation & Tissues & mTOR & {$[61]$} \\
\hline Cervical cancer & Down regulation & Tissues & PLK1 & {$[62,63]$} \\
\hline $\begin{array}{l}\text { Small cell carcinoma of the cervix } \\
\text { (SCCC) }\end{array}$ & Down regulation & Tissues & Not clear & [64] \\
\hline Prostate cancer & Downregulation & Tissues/Cell lines & $\begin{array}{l}\text { SMARCA5,BAZ2A,THAP2, mTOR, FGFR3, } \\
\text { Argonaute } 2\end{array}$ & {$[65-70]$} \\
\hline Colorectal cancer(CRC) & Down regulation & Tissues & RAP1B & {$[71-73]$} \\
\hline Chondrosarcomas & Down regulation & Cell lines & mTOR & {$[74]$} \\
\hline Osteosarcoma (OS) & Down regulation & Tissues & Cyr61, FGFR3. & {$[75,76]$} \\
\hline Glioblastoma (GBM) & Down regulation & Cell lines & SMRT/NCOR2 & {$[77]$} \\
\hline $\begin{array}{l}\text { Acute lymphoblastic } \\
\text { leukaemia(ALL) }\end{array}$ & Down regulation & myeloid cells & FKBP51, IGF1R/mTOR & [78-81] \\
\hline Small cell lung cancer (SCLC) & Up regulation & Tissues & HOXA1 & {$[82]$} \\
\hline Renal cell carcinoma(RCC) & Up regulation & Tissues & Not clear & [90] \\
\hline Acute myeloid leukemia (AML) & Up regulation & myeloid cells & RBSP3,mTOR, pRB/E2F1 & {$[91-94]$} \\
\hline
\end{tabular}


Fig. 2. Overview of numerous target genes of miR-100. Numerous genes have been confirmed as targets for miR-100, which covers multiple biological signaling pathways, including cellular proliferation, apoptosis, invasion, metastasis and differentiation. Symbols : $\rightarrow$ activation; ${ }_{\perp}$ inhibition.

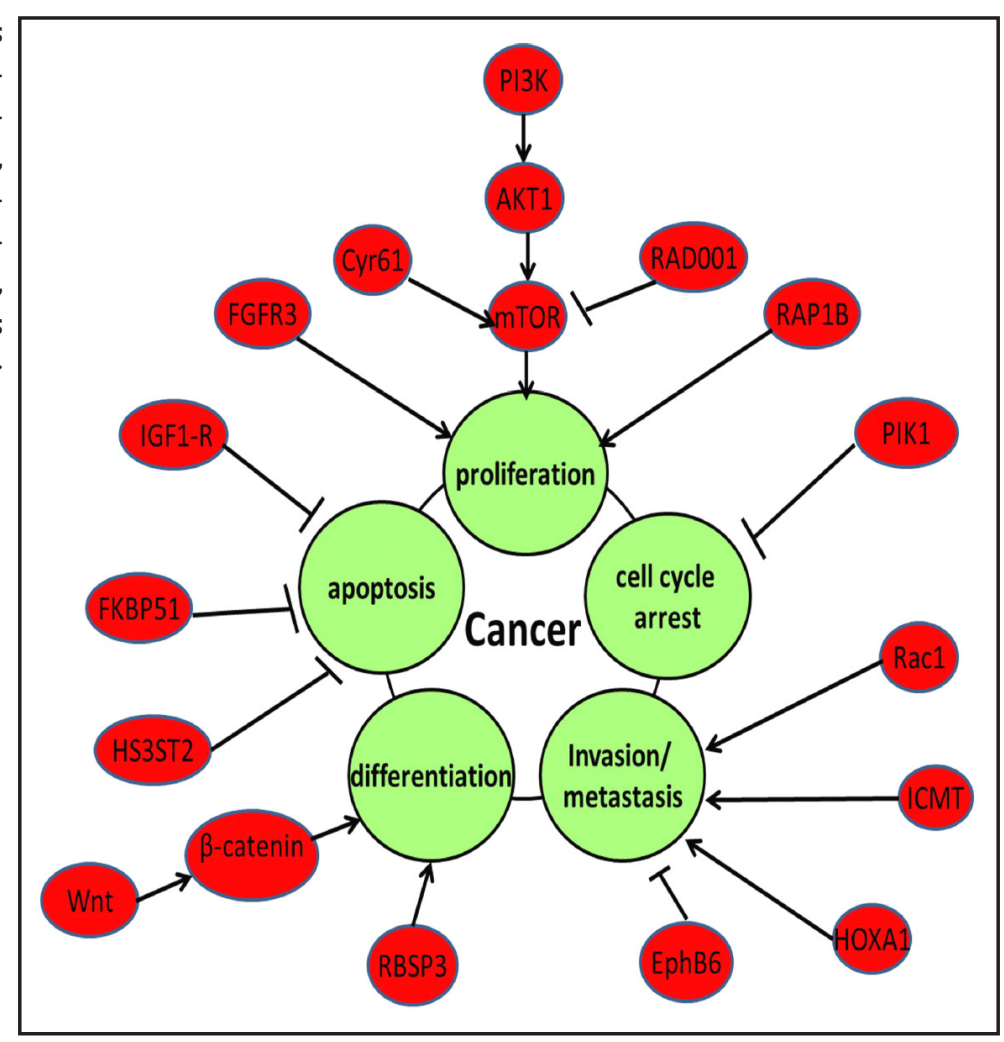

of miR-100 has been also found in small cell lung cancer (SCLC) [82], NSCLC [83, 84], GC [7, 9, 85], HCC [86], pancreatic adenocarcinoma [87-89], renal cell carcinoma (RCC) [90], acute myeloid leukemia (AML) [91-94]. However, the expression levels of miR-100 in the same cancer type could be different, which is dependent on the tumor samples obtaining in cancer cell lines or in cancer tissues, as well as plasma. The discrepant expression is still difficult to explain at the time.

The different roles of miR-100 in tumorigenesis might depend on tumor types and its target genes in different cells. Previously, Zheng and his colleague reported that miR-100 was up-regulated in childhood AML and overexpression of miR-100 inhibited the differentiation of granulocyte and monocyte cells and promoted cell survival [94]. On the contrary, they found that miR-100 was down-regulated in childhood ALL and ectopic expression of miR-100 inhibited cell proliferation and enhanced dexamethasone-induced cell apoptosis [80]. Also, Leite's study showed that the expression of miR-100 was reduced during the transition from high grade localized prostate cancer to metastasis [68]. However, conversely, patients with higher levels of miR-100 expression were more prone to suffer biochemical recurrence after radical prostatectomy [69]. Based on experimental results, they pointed out that miR-100 was a context-dependent miRNA in prostate cancer which influenced the fate of tumor cells. On the one hand, oncogenic miR-100 increases cell proliferation through the pRb pathway by down-regulating SMARCA5, BAZ2A and THAP2; on the other hand, miR-100 could also act as a tumor suppressor, cooperating with other factors to down-regulate the mTOR pathway [66]. So far, the molecular bases of these interactions and status of downstream targets of miR-100 have been studied by many scientists. However, the mechanisms responsible for its dysregulation are largely unknown and need to be further elucidated.

\section{The functions of miR-100 and its target genes in human cancers}

To date, numerous genes have been testified as target genes of miR-100, which covers multiple biological signaling pathways, affecting formation of many malignant phenotypes 


\section{Cellular Physiology Cell Physiol Biochem 2015;37:2143-2159

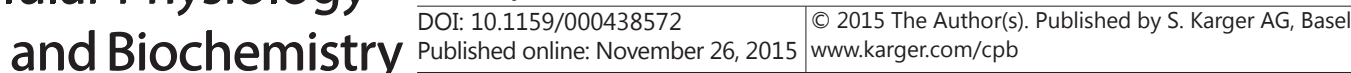 \\ Li et al.: MiR-100: A Potential Therapeutic Target for Human Cancers}

including cellular proliferation, differentiation, invasion, metastasis, angiogenesis and apoptosis in heterogeneous tumors (Fig. 2). For example, miR-100 could suppress proliferation, induce apoptosis and cell cycle arrest in tumor cells by targeting multiple tumor-related genes such as mTOR, PI3K, AKT1, IGF1-R, HS3ST2, HOXA1, RAP1B, FGFR3, PIK1, Cyr61, FKBP51 [7, 58, 61, 72, 75, 76, 80, 87, 95]. Direct regulation of some oncogenes involved in tumor cell invasion and metastasis, such as HOXA1, Rac1, ICMT, EphB6, AGO2 by miR-100 has been identified in many cancers $[32,41,67,96]$. In addition, there is evidence that miR-100 has an important role in regulating cell differentiation by targeting core reprogramming factors including Plk1, Wht, $\beta$-catenin or RBSP3 [34, 94]. Although miR-100 exerts a potent tumor-regulatory effect by regulating multiple target genes, the number of target genes is still growing, which suggests a complicated regulatory network for miR-100 in human cancers.

\section{MiR-100 in cancer proliferation and apoptosis}

The phosphatidylinositol 3-kinase (PI3K) / v-akt murine thymoma viral oncogene homolog 1 (AKT1) / mammalian target of rapamycin (mTOR) pathway is a key signaling system related to tumor cell proliferation and apoptosis [58, 97]. As a member of PI3Krelated kinase family, mTOR (locus $1 \mathrm{p} 36.2$ ) interacts with special proteins to form two distinct complexes, mTOR complex 1 (mTORC1) and 2 (mTORC2) and regulates protein synthesis and cell growth $[61,98]$. Torres et al. described down-regulation of miR-100 in EEC, which was accompanied by increasing expression of its target gene mTOR to regulate cell proliferation [61]. Similarly, mTOR is also involved in the ability of miR-100 ability to suppress cell proliferation and colony formation in bladder cancer [50]. It was demonstrated by Sun et al. that miR-100 was significantly decreased in ESCC and the tumor suppressor function of miR-100 resulted from inhibiting tumor cell growth and inducing apoptosis by targeting mTOR [27]. As an mTOR inhibitor, the rapamycin analog RAD001 has recently been shown to decrease tumor growth in a xenograft model of clear cell ovarian cancer [95]. Ankur et al. showed that up-regulation of miR-100 inhibited mTOR signaling and enhanced sensitivity to RAD001 [58]. Interestingly, Huang and his colleagues identified for the first time that miR100 might act as a tumor suppressor in the progression of osteosarcoma by controlling the direct target gene Cyr61 [75, 99]. It has been reported that Cyr61 promotes cell proliferation and inhibit cell apoptosis by binding to different types of integrin molecules, which resulted in down-regulating p53 expression and up-regulating NF- $\mathrm{BB}$ expression through PI3K/Akt/ mTOR pathways $[100,101]$. Therefore, targeting miR-100/mTOR signaling pathway will be a potential strategy for inhibition of proliferation and induction of apoptosis in human cancers.

Bi et al. reported lower levels of miR-100 and higher levels of fibroblast growth factor receptor 3 (FGFR3) in the osteosarcoma specimen compared to the paired normal bone tissues, and their further research work indicated that miR-100 could inhibit growth of osteosarcoma cells through binding to the 3'-UTR of FGFR3 mRNA [76, 102]. Similarly, Blick et al. showed that low expression of miR-100 could increase FGFR3 expression to stimulate cell proliferation in non-muscle invasive bladder cancer [48]. As well, Morais and his colleagues showed that miR-100 is involved in bladder urothelial carcinogenesis by changing the expression levels of mRNA and proteins of genes related to cell proliferation, survival, apoptosis and chromosomal stability [54]. In addition, Peng et al. showed that miR100 functioned as a tumor suppressor in colorectal cancer by targeting RAP1B [72].

The process of tumorigenesis is the result of a variety of complex factors, in which evasion of apoptosis is one of the crucial acquired capabilities used to promote cancer cell survival and proliferation [103-106]. However, the molecular bases of miR-100 involved in regulation of apoptosis in tumor cells remain uncharacterized. Insulin growth factor-1 receptor (IGF1-R) plays an important role in cell longevity and proliferation and its downregulation can lead to cell death [107]. Huang et al. indicated that overexpression of miR100 in pancreatic adenocarcinoma directly targeted IGF1-R to control cell apoptosis [87]. Previous studies have shown that the mTOR signaling is closely interconnected with the IGF 
pathway since it can be activated by upstream IGF receptor signaling. Chen et al. showed that down-regulation of miR-99 family contributed to HNSCC tumorigenesis, in part by targeting IGF1-R/mTOR signaling to regulate cell proliferation and apoptosis [22]. Similarly, the IGF-mTOR signaling is also involved in regulation of adrenocortical cancer cell apoptosis by miR-100 [45]. FKBP51, a 51-kDa FK506 binding protein, exerts proliferative and antiapoptotic properties via inactivation of the glucocorticoid receptor (GR) signaling pathway by reducing GR activity and impairing GR nuclear translocation [108-110]. Li and other researchers' experimental data indicated that miR-100, a tumor suppressor in ALL, was involved in two essential signaling pathways to inhibit cell growth and initiate cell apoptosis: (i) influencing GR activity by targeting FKBP51; (ii) down-regulating the expression of the anti-apoptotic gene MCL1 by suppressing the IGF1R/mTOR pathway [80]. In another report, Ge et al. showed that overexpression of miR-100 could lead to autophagy of HCC cells by inhibiting expression of mTOR and IGF-1R [38]. As the target gene of miR-100, HS3ST2 gene was reported to encode an important enzyme participating in the final modification of heparan sulfate proteoglycans (HSPGs), which plays vital roles in tumor progression. Also, the absence of HS3ST2 would result in aberrant modulation of key HS biosynthetic enzymes in several cancers including breast, lung, pancreatic, and colorectal cancers $[111,112]$. Based on Yang's investigation, miR-100 functions as a key suppressor of apoptosis in GC by down-regulating expression of HS3ST2 to inactivate the Notch signaling pathway $[7,113]$. In addition, Ghose and Bhattacharyya's work firstly reported transcriptional regulation of microRNA-100, -146a, and -150 genes by p53 and NF-kappaB p65/RelA in mouse striatal STHdh/ Hdh cells and human cervical carcinoma cells [114].

Liu and his colleagues firstly reported that miR-100 was significantly lower in NSCLC tissues than in normal tissues and its overexpression could lead to $G_{2} / M$ cell cycle arrest in NSCLC cell by binding the 3'-UTR of polo-like kinase 1 (PIK1) transcripts [36]. PIK1, a kind of conserved serine/threonine kinases, is involved in the control of the $G_{2} / M$ phase, and its overexpression is significantly correlated with malignant phenotypes including higher clinical stage, advanced tumor classification and lymph node metastasis of cancers [115117]. In HCC, PIK1 is also reported to be involved in miR-100's ability to impair the growth ability of cancer cells and their capability to form colonies [39]. Bao et al. showed a gradually decreased tendency of miR-100 expression in cervical cancer tissues, and further results indicated that downregulation of miR-100 leads to an increase in Plk1 leading to cell cycle progression in cervical cancer [62]. Consistent with these results, the miR-100-induced $G_{2} / M$ arrest is medicated by PIK1 in nasopharyngeal cancer progression [24]. Similarly, Dong et al. also revealed that miR-100 could affect the growth of epithelial ovarian cancer cells by posttranscriptionally regulating target PIK1 expression [60].

\section{MiR-100 in cancer invasion and metastasis}

Metastasis is one of the causes of tumor recurrence and cancer mortality. The ability of tumor cells to invade and destroy neighboring tissues and organs, as well as migrate to other parts of the body, is crucial to the metastatic process $[118,119]$. It has been increasingly recognized that miRNAs play important roles in tumor invasiveness and metastasis [120122]. For example, Shi et al. showed that lower expression of miR-100 could promote the migration and invasion of gastric cancer cells without significant alteration of proliferation [8]. Also, Fu et al. showed that miR-100 was involved in ESCC metastasis and introduction of miR-100 could strikingly inhibit cell invasion and migration of ESCC cells [26]. Rac1, the most extensively studied isoform in Rac subfamily, is found to be significantly overexpressed in metastatic and aggressive HCCs [123]. As the upstream regulator of Rac1, ICMT is an essential post-prenylation-processing enzyme, which methylates a group of proteins including Rho GTPases [124]. Zhou et al. found that miR-100 exerted its anti-metastasis function by directly repressing expression of ICMT and Rac1, and consequently abrogating the Rac1 signaling [41]. In addition, miR-100 inhibits the motility and invasiveness of mammary tumor cells through direct repressing HOXA1 [32]. EphB6 can affect the expression of a variety of proteins, which are involved in cytoskeleton, signal transduction,

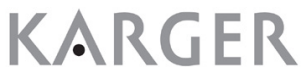


metabolism and energy homeostasis [125]. In previous research, the expression of EphB6 receptor has been reported to be transcriptionally silenced in invasive breast carcinoma cells [126]. Bhushan et al. showed that miR-100 in breast cancer could target the kinasedeficient EphB6 receptor to initiate signal transduction from the cell surface to the nucleus and alter tumorigenesis and invasion [96]. Moreover, Zhang et al. demonstrated that miR100 modulated the migration and invasion of ESCC cells by targeting the mTOR 3'-UTR, and its downregulation in ESCC tissues was significantly correlated with status of lymph node metastasis in patients [30]. Argonaute 2 (AGO2), the core effector protein of the miRNAinduced silencing complex promotes tumor metastasis. Wang et al. showed that loss of miR100 promoted the metastatic ability of prostate cancer cells through modulating migration, invasion, epithelial-mesenchymal transition (EMT) and stemness of cancer cells by upregulating AGO2 expression [67, 127]. With biological properties similar to normal adult stem cells, cancer stem cells (CSCs) play central roles in malignant tumor onset, progression, recurrence, metastasis and drug resistance [128]. In addition, EMT allows cancer cells to metastasize by changing proliferating cells from an aplanetic state to a motile state and one of its biomarker is the loss of E-cadherin [129]. Shimamura et al. applied Network Profiler to microarray gene expression and extracted the system changes that were related to EMT, and further found that higher expression of miR-100 could significantly decrease E-cadherin expression and induce morphological changes of EMT [130].

The roles of miR-100 in differentiation of cancer stem cells

Studies performed over the past years have demonstrated that miRNAs can sustain stemness of embryonic stem cells (ESCs), regulate ESC differentiation, as well as controlling self-renewal and differentiation of CSCs [131-133]. CSCs are characterized by self-renewal and high tumorigenic capacity and can be formed during the process of EMT. Petrelli et al. found that miR-100 induced a differential program by the Wnt / $\beta$-catenin pathway which is one of the main signal pathways involved in differentiation of CSCs and could inhibit maintenance and expansion of CSCs in basal-like cancer through the down-regulation of Plk1 [34]. In addition, Zheng and his colleagues revealed that miR-100 could modulate the cell cycle effectors pRB / E2F1 including regulating G1/S transition and S-phase entry and blocked granulocyte / monocyte differentiation in acute myeloid leukemia (AML) by targeting RBSP3, which is a phosphatase-like tumor suppressor [94].

\section{MiR-100 in cancer diagnosis and prognosis}

Specific miRNAs have been found to be differentially expressed in the majority of tumor cases, suggesting that miRNA expression patterns are capable of distinguishing between malignant and normal tissues [134, 135]. There is increasing evidence to show that tumor-derived circulating miRNAs have diagnostic or prognostic potential because of their remarkable stability in blood and their characteristic expression in cancers [136138]. During the past few years, the roles of miR-100 in diagnosis of human cancers are increasingly reported. For example, a noticeable decrease in miR-100 was observed in human PC tissues compared to normal prostate tissues and in bone metastatic PC tissues compared to primary PC tissues [67]. Also, Shi et al. showed that the expression of miR100 was lower in GC tissues as compared with control tissues [8]. In contrast, Yang et al. detected up-regulation of miR-100 in human epithelium-derived GC cells [7]. The discrepant expression is still difficult to explain at the time. In another study, miR-100 was observed to be reduced about fourfold in invasive human breast cancer tissues as compared with benign patient samples [33]. Similarly, miR-100 was found to be down-regulated in all subtypes of breast cancers including luminal A, luminal B, basal-like and HER2 subtypes, compared with paired normal breast tissues [32]. Recently, the lower expression of miR-100 in bladder cancer tissues compared to adjacent noncancerous tissues is reported to be correlated with low-grade, non-invasive bladder urothelial cancer [50, 52, 54]. In ESCC, miR-100 
demonstrated markedly lower expression in tumor tissues than in controls as validated by quantitative reverse transcription-polymerase chain reaction [30]. Feng et al. found that the expression of miR-100 in docetaxel-resistant lung adenocarcinoma cell line (SPC-A1/DTX) is significantly lower than that in parental SPC-A1 cells [35]. Also, the expression level of miR100 was significantly decreased in osteosarcoma tissues in comparison with the adjacent normal tissues $[75,139]$. Likewise, miR-100 was also found to be markedly under-expressed in both pancreatic cancer cell lines and tumor cells from patients [42]. Using microarray analysis to compare the expression of miR-100 in five pancreatic cancer cell lines of which two that can metastasized in vivo and three that did not metastasize, Huang et al. showed that miR-100 is significantly up-regulated in metastatic tumor cells [87].

Recently, as a non-invasive, blood-based diagnostic tool, cell-free miRNA has obtained much interest [140,141]. By comparing blood serum samples from 50 gastric patients and 47 healthy controls, Wang et al. confirmed the diagnostic value of serum miR-100 higher regulation in human GC [9]. The Solexa sequencing results from Zhang et al. demonstrated marked upregulation of 25 serum miRNAs including miR-100 in ESCC patients compared with controls [29]. Similarly, together with the other six serum miRNAs, miR-100 was found to be significantly higher in ESCC than in controls [28]. From those above studies, it was concluded that miR-100 might be a more reliable diagnostic biomarker for human cancers as a result of its aberrant expression in tumorigenesis.

Meanwhile, the associations of miR-100 with clinical outcome of human cancer patients were also reported. In terms of SCLC, Xiao et al. confirmed that the expression level of miR100 was inversely correlated with the expression of its target gene HOXA1 and associated with the poor prognosis of SCLC patients [82]. Wang et al. showed that overexpression of miR-100 in RCC tissues was associated with advanced tumor T stage, grade, the presence of metastasis and poor prognosis of patients [90]. Moreover, low expression of miR-100 was testified to be a negative prognostic factor, associating with gene signatures of high grade undifferentiated breast cancer [34]. Wang et al. showed that down-regulation of miR-100 in bladder cancer tissues was associated with shorter overall survival and poor progressionfree survival of patients [51]. In addition, by detecting the expression of miR-100 in 120 self-paired specimens of ESCC and adjacent normal tissues by RT-PCR, Zhou et al. found that the expression of miR-100 in ESCC tissues was significantly lower than that in the adjacent normal tissues and could predict advanced clinical stage, depth of tumor invasion, and the presence of distant metastasis [31]. In CRC, low miR-100 expression was observed to be significantly connected with advanced TNM stage, larger tumor size, and higher incidence of lymph node metastasis, together with shorter overall survival, suggesting that miR-100 could serve as an independent unfavorable prognostic predictor [71]. Similarly, low miR-100 expression was found to be closely correlated with higher clinical stage, advanced tumor classification and lymph node metastasis of NSCLC patients, suggesting that low miR-100 expression might be a poor prognostic factor in NSCLC [36]. At the same time, Zhou et al. showed that down-regulation of miR-100 in HCC tissues was significantly associated with advanced TNM stage, poorer cell differentiation, venous invasion, tumor nodule without complete capsule and shorter recurrence-free survival of patients [41]. In other two studies, miR-100 was reported to function as a tumor suppressor by targeting plk1 in HCC and be correlated with higher incidence of lymph node metastasis and poor prognosis in HCC patients $[37,142]$. Therefore, it was concluded that low expression level of miR-100 could not only predict unfavorable prognosis of HCC patients but also have the capacity to predict further risk stratification in the treatment of HCC. What's more, overexpression of miR-100 in pediatric AML was found to be associated with poor relapse-free and overall survival of patients [91]. In contrast, Li et al. observed that miR-100 was down-regulated in 111 ALL patients, especially in high-risk groups and its lower expression level was correlated with shorter 5-year survival of patients [80]. In another study, Peng et al. showed that low miR100 expression was closely correlated with higher serum CA125 expression level, lymph node involvement, advanced FIGO stage and short overall survival of epithelial ovarian cancer (EOC) patients, suggesting that the status of miR-100 expression could be an independent 
predictor of overall survival in EOC [60]. Taken together, miR-100 can serve as a candidate prognostic indicator, but further investigation of a larger patient population is necessary to confirm prognostic evaluation of miR-100 in human cancers.

\section{MiR-100 in cancer therapy}

MiR-100 can be overexpressed or under-expressed in different cancers, so silencing of miR-100 that is overexpressed or replacement of miR-100 that is under-expressed are two distinct and novel approaches to treat tumors driven by miR-100 dysregulation [143]. The observation of decreased levels of tumor suppressive miRNAs including miR-100 in cancers has led to the concept of miRNA replacement therapy. For example, Li et al. reported that transfection of lentivirual vector containing miR-100 mimics in pancreatic cancer cells could inhibit cancer cell proliferation and increase sensitivities to cisplatin through targeting FGFR3 [42]. Zhu et al. also highlighted miR-100 as a tumor suppressor in chondrosarcoma and obtained evidence that overexpression of miR-100 could reverse the chemoresistance of cisplatin-resistant chondrosarcoma cells to cisplatin by directly targeting mTOR [74]. In addition, upregulated miR-100 with oncogenic potential in specific cancer types can be potential therapeutic targets for inhibition by using antisense oligonucleotides, sponges or locked nucleic acid (LNA) constructs [144-146]. However, the inhibition of miR-100 for therapy has not been demonstrated in certain cases.

On the other hand, differentiation therapy is a promising therapeutic strategy which is achieved by using drugs to force malignant cells to terminally differentiate and taking advantage of differentiation molecules that are specifically expressed in the selected tissue. Therefore, this therapy can reduce side effects in patients, since it avoids indiscriminately killing proliferating cells and instead concentrates its efficacy on cancer cells. Interfering with estrogen receptor (ER) activation is currently the gold standard for the treatment of breast cancer [147]. By promoting the expression of a functional ER, converting a basal like phenotype into luminal, miR-100 renders basal-like BrCSCs responsive to hormonal therapy [34]. In addition, despite the great advances achieved in radiotherapy and cytotoxic drug development, long term cure rates by standard therapies are disappointing owing to disseminated disease at diagnosis and chemotherapeutic resistance[148]. Ectopic miRNAs are involved in various drug resistant mechanisms including EMT, CSC, apoptosis avoidance, androgen signaling and multiple drug resistance (MDR) transporters [78, 149, 150]. Additionally, miR-100 can influence the sensitivity of tumors to chemo- or radiation therapy, so a combination of miR-100 chemo- or radiation therapy proves to be a novel antitumor strategy. In the study of Feng et al. showed that introduction of miR-100 could significantly sensitize SPC-A1/DTX cells to docetaxel via inducing significant suppression of cell proliferation, cell arrest in $\mathrm{G}_{2} / \mathrm{M}$ phase of cell cycle and enhancement of apoptosis by targeting Plk1 $[35,151]$. Lobert et al. initially reported that down-regulation of miR-100 could increase $\beta$-tubulin class $V$ expression level to promote the continuing survival and proliferation of tumor cells, suggesting special implications for paclitaxel resistance and potential miR-100 replacement therapy in combination with paclitaxel [152]. Also, Ng et al. demonstrated for the first time that overexpression of miR-100 promoted the low expression of activating ataxia telangiectasia mutated (ATM, an important checkpoint regulator for promoting homologous recombination repair) in human glioma cell line and restoration of miR-100 could sensitize tumor cells to radiotherapy or chemotherapy [153].

\section{Conclusions and Future Directions}

In summary, much evidence indicates that aberrant miR-100 expression is commonly found in different human cancers and miR-100 functions as a potent tumor suppressor / promotor. More importantly, the expression patterns and effects of miR-100 in tumor 
progression are not fully elucidated and the recent studies have reported controversial results. Since miR-100 has been reported to be significantly dysregulated in different cancer types, it is expected to be a valuable molecular marker for cancer diagnosis and prognosis. Understanding the roles of these altered miRNAs and its possible molecular mechanisms in physiological and pathological processes of cells will be helpful to provide an opportunity for possible therapeutic intervention in disease processes by targeting either the regulatory pathways or the miRNAs themselves. Since transfection of miR-100 could improve the sensitivity to chemotherapy agents and radiation therapy in cancer cells, targeting miR-100 may provide a new strategy for overcoming therapy resistance in clinic. Research into miR100-based therapy, however, is at an early stage, and further investigation of miR-100 may lead to novel therapeutic strategies for human cancers in future.

\section{Acknowledgements}

The work was supported by grants from the National Natural Science Foundation of China (No.81172335 and 81472266) and the Excellent Youth Foundation of Jiangsu Province, China (BK20140032). We apologize to all colleagues whose relevant contributions could not be cited due to space limitations.

\section{Disclosure Statement}

The authors declare that they have no conflicts of interest related to this work.

\section{References}

1 Bartel DP: MicroRNAs: genomics, biogenesis, mechanism, and function. Cell 2004;116:281-297.

2 Song JL, Nigam P, Tektas SS, Selva E: microRNA regulation of Wnt Signaling Pathways in Development and Disease. Cell Signal 2015;27:1380-1391.

3 Landau DA, Slack FJ: MicroRNAs in mutagenesis, genomic instability, and DNA repair. Semin Oncol 2011;38:743-751.

4 Bartel DP: MicroRNAs: target recognition and regulatory functions. Cell 2009;136:215-233.

5 Lu J, Getz G, Miska EA, Alvarez-Saavedra E, Lamb J, Peck D, Sweet-Cordero A, Ebert BL, Mak RH, Ferrando AA, Downing JR, Jacks T, Horvitz HR, Golub TR: MicroRNA expression profiles classify human cancers. Nature 2005;435:834-838.

6 Hertel J, Bartschat S, Wintsche A, Otto C, Stadler PF: Evolution of the let-7 microRNA family. RNA Biol 2012;9:231-241.

7 Yang G, Gong Y, Wang Q Wang Y, Zhang X: The role of miR-100-mediated Notch pathway in apoptosis of gastric tumor cells. Cell Signal 2015;27:1087-101.

8 Shi DB, Xing AY, Gao C, Gao P: [Expression of microRNA-100 in human gastric cancer]. Zhonghua Bing Li Xue Za Zhi 2013;42:15-19.

9 Wang H, Wang L, Wu Z, Sun R, Jin H, Ma J, Liu L, Ling R, Yi J, Wang L, Bian J, Chen J, Li N, Yuan S, Yun J: Three dysregulated microRNAs in serum as novel biomarkers for gastric cancer screening. Med Oncol 2014;31:298.

10 Qin C, Huang RY, Wang ZX: Potential role of miR-100 in cancer diagnosis, prognosis, and therapy. Tumour Biol 2015;36:1403-1409.

11 Cullen BR: Transcription and processing of human microRNA precursors. Mol Cell 2004;16:861-865.

12 Lee Y, Ahn C, Han J, Choi H, Kim J, Yim J, Lee J, Provost P, Radmark O, Kim S, Kim VN: The nuclear RNase III Drosha initiates microRNA processing. Nature 2003;425:415-419.

13 Zeng Y, Cullen BR: Sequence requirements for micro RNA processing and function in human cells. Rna 2003;9:112-123. 


\section{Cellular Physiology Cell Physiol Biochem 2015;37:2143-2159 \begin{tabular}{l|l|l}
\hline DOI: 10.1159/000438572 & $\begin{array}{l}\text { C) } 2015 \text { The Author(s). Published by S. Karger AG, Basel } \\
\text { www.karger.com/cpb }\end{array}$ \\
and Biochemistry
\end{tabular}}

Li et al.: MiR-100: A Potential Therapeutic Target for Human Cancers

14 Cai X, Hagedorn CH, Cullen BR: Human microRNAs are processed from capped, polyadenylated transcripts that can also function as mRNAs. Rna 2004;10:1957-1966.

15 Lee Y, Kim M, Han J, Yeom KH, Lee S, Baek SH, Kim VN: MicroRNA genes are transcribed by RNA polymerase II. EMBO J 2004;23:4051-4060.

16 Bohnsack MT, Czaplinski K, Gorlich D: Exportin 5 is a RanGTP-dependent dsRNA-binding protein that mediates nuclear export of pre-miRNAs. Rna 2004;10:185-191.

17 Lund E, Guttinger S, Calado A, Dahlberg JE, Kutay U: Nuclear export of microRNA precursors. Science 2004;303:95-98.

18 Schwarz DS, Hutvagner G, Du T, Xu Z, Aronin N, Zamore PD: Asymmetry in the assembly of the RNAi enzyme complex. Cell 2003;115:199-208.

19 Hammond SM, Bernstein E, Beach D, Hannon GJ: An RNA-directed nuclease mediates post-transcriptional gene silencing in Drosophila cells. Nature 2000;404:293-296.

20 Medina PP, Slack FJ: microRNAs and cancer: an overview. Cell Cycle 2008;7:2485-2492.

21 Chen D, Cabay RJ, Jin Y, Wang A, Lu Y, Shah-Khan M, Zhou X: MicroRNA Deregulations in Head and Neck Squamous Cell Carcinomas. J Oral Maxillofac Res 2013;4:e2.

22 Chen Z, Jin Y, Yu D, Wang A, Mahjabeen I, Wang C, Liu X, Zhou X: Down-regulation of the microRNA-99 family members in head and neck squamous cell carcinoma. Oral Oncol 2012;48:686-691.

23 Dai Y, Xie CH, Neis JP, Fan CY, Vural E, Spring PM: MicroRNA expression profiles of head and neck squamous cell carcinoma with docetaxel-induced multidrug resistance. Head Neck 2011;33:786-791.

24 Shi W, Alajez NM, Bastianutto C, Hui AB, Mocanu JD, Ito E, Busson P, Lo KW, Ng R, Waldron J, O'Sullivan B, Liu FF: Significance of Plk1 regulation by miR-100 in human nasopharyngeal cancer. Int J Cancer 2010;126:2036-2048.

25 Henson BJ, Bhattacharjee S, O'Dee DM, Feingold E, Gollin SM: Decreased expression of miR-125b and miR100 in oral cancer cells contributes to malignancy. Genes Chromosomes Cancer 2009;48:569-582.

26 Fu HL, Wu de P, Wang XF, Wang JG, Jiao F, Song LL, Xie H, Wen XY, Shan HS, Du YX, Zhao YP: Altered miRNA expression is associated with differentiation, invasion, and metastasis of esophageal squamous cell carcinoma (ESCC) in patients from Huaian, China. Cell Biochem Biophys 2013;67:657-668.

27 Sun J, Chen Z, Tan X, Zhou F, Tan F, Gao Y, Sun N, Xu X, Shao K, He J: MicroRNA-99a/100 promotes apoptosis by targeting mTOR in human esophageal squamous cell carcinoma. Med Oncol 2013;30:411.

28 Wu C, Wang C, Guan X, Liu Y, Li D, Zhou X, Zhang Y, Chen X, Wang J, Zen K, Zhang CY, Zhang C: Diagnostic and prognostic implications of a serum miRNA panel in oesophageal squamous cell carcinoma. PLoS One 2014;9:e92292.

29 Zhang C, Wang C, Chen X, Yang C, Li K, Wang J, Dai J, Hu Z, Zhou X, Chen L, Zhang Y, Li Y, Qiu H, Xing J, Liang Z, Ren B, Yang C, Zen K, Zhang CY: Expression profile of microRNAs in serum: a fingerprint for esophageal squamous cell carcinoma. Clin Chem 2010;56:1871-1879.

30 Zhang N, Fu H, Song L, Ding Y, Wang X, Zhao C, Zhao Y, Jiao F, Zhao Y: MicroRNA-100 promotes migration and invasion through mammalian target of rapamycin in esophageal squamous cell carcinoma. Oncol Rep 2014;32:1409-1418.

31 Zhou S, Yang B, Zhao Y, Xu S, Zhang H, Li Z: Prognostic value of microRNA-100 in esophageal squamous cell carcinoma. J Surg Res 2014;192:515-520.

32 Chen D, Sun Y, Yuan Y, Han Z, Zhang P, Zhang J, You MJ, Teruya-Feldstein J, Wang M, Gupta S, Hung MC, Liang H, Ma L: miR-100 induces epithelial-mesenchymal transition but suppresses tumorigenesis, migration and invasion. PLoS Genet 2014;10:e1004177.

33 Gebeshuber CA, Martinez J: miR-100 suppresses IGF2 and inhibits breast tumorigenesis by interfering with proliferation and survival signaling. Oncogene 2013;32:3306-3310.

34 Petrelli A, Carollo R, Cargnelutti M, Iovino F, Callari M, Cimino D, Todaro M, Mangiapane LR, Giammona A, Cordova A, Montemurro F, Taverna D, Daidone MG, Stassi G, Giordano S: By promoting cell differentiation, miR-100 sensitizes basal-like breast cancer stem cells to hormonal therapy. Oncotarget 2015;6:2315-2330.

35 Feng B, Wang R, Chen LB: MiR-100 resensitizes docetaxel-resistant human lung adenocarcinoma cells (SPC-A1) to docetaxel by targeting Plk1. Cancer Lett 2012;317:184-191.

36 Liu J, Lu KH, Liu ZL, Sun M, De W, Wang ZX: MicroRNA-100 is a potential molecular marker of non-small cell lung cancer and functions as a tumor suppressor by targeting polo-like kinase 1. BMC Cancer 2012;12:519.

37 Chen P, Zhao X, Ma L: Downregulation of microRNA-100 correlates with tumor progression and poor prognosis in hepatocellular carcinoma. Mol Cell Biochem 2013;383:49-58. 


\section{Cellular Physiology Cell Physiol Biochem 2015;37:2143-2159 \begin{tabular}{l|l|l|l} 
DOI: 10.1159/000438572 & (c) 2015 The Author(s). Published by S. Karger AG, Basel \\
www.karger.com/cpb
\end{tabular} \\ Li et al.: MiR-100: A Potential Therapeutic Target for Human Cancers}

38 Ge YY, Shi Q, Zheng ZY, Gong J, Zeng C, Yang J, Zhuang SM: MicroRNA-100 promotes the autophagy of hepatocellular carcinoma cells by inhibiting the expression of mTOR and IGF-1R. Oncotarget 2014;5:62186228.

39 Petrelli A, Perra A, Schernhuber K, Cargnelutti M, Salvi A, Migliore C, Ghiso E, Benetti A, Barlati S, LeddaColumbano GM, Portolani N, De Petro G, Columbano A, Giordano S: Sequential analysis of multistage hepatocarcinogenesis reveals that miR-100 and PLK1 dysregulation is an early event maintained along tumor progression. Oncogene 2012;31:4517-4526.

40 Tovar V, Alsinet C, Villanueva A, Hoshida Y, Chiang DY, Sole M, Thung S, Moyano S, Toffanin S, Minguez B, Cabellos L, Peix J, Schwartz M, Mazzaferro V, Bruix J, Llovet JM: IGF activation in a molecular subclass of hepatocellular carcinoma and pre-clinical efficacy of IGF-1R blockage. J Hepatol 2010;52:550-559.

41 Zhou HC, Fang JH, Luo X, Zhang L, Yang J, Zhang C, Zhuang SM: Downregulation of microRNA-100 enhances the ICMT-Rac1 signaling and promotes metastasis of hepatocellular carcinoma cells. Oncotarget 2014;5:12177-12188.

42 Li Z, Li X, Yu C, Wang M, Peng F, Xiao J, Tian R, Jiang J, Sun C: MicroRNA-100 regulates pancreatic cancer cells growth and sensitivity to chemotherapy through targeting FGFR3. Tumour Biol 2014;35:1175111759.

43 Permuth-Wey J, Chen YA, Fisher K, McCarthy S, Qu X, Lloyd MC, Kasprzak A, Fournier M, Williams VL, Ghia KM, Yoder SJ, Hall L, Georgeades C, Olaoye F, Husain K, Springett GM, Chen DT, Yeatman T, Centeno BA, Klapman J, Coppola D, Malafa M: A genome-wide investigation of microRNA expression identifies biologically-meaningful microRNAs that distinguish between high-risk and low-risk intraductal papillary mucinous neoplasms of the pancreas. PLoS One 2015;10:e0116869.

44 Jung DE, Wen J, Oh T, Song SY: Differentially expressed microRNAs in pancreatic cancer stem cells. Pancreas 2011;40:1180-1187.

45 Doghman M, El Wakil A, Cardinaud B, Thomas E, Wang J, Zhao W, Peralta-Del Valle MH, Figueiredo BC, Zambetti GP, Lalli E: Regulation of insulin-like growth factor-mammalian target of rapamycin signaling by microRNA in childhood adrenocortical tumors. Cancer Res 2010;70:4666-4675.

46 Ratert N, Meyer HA, Jung M, Lioudmer P, Mollenkopf HJ, Wagner I, Miller K, Kilic E, Erbersdobler A, Weikert S, Jung K: miRNA profiling identifies candidate mirnas for bladder cancer diagnosis and clinical outcome. J Mol Diagn 2013;15:695-705.

47 Song T, Xia W, Shao N, Zhang X, Wang C, Wu Y, Dong J, Cai W, Li H: Differential miRNA expression profiles in bladder urothelial carcinomas. Asian Pac J Cancer Prev 2010;11:905-911.

48 Blick C, Ramachandran A, Wigfield S, McCormick R, Jubb A, Buffa FM, Turley H, Knowles MA, Cranston D, Catto J, Harris AL: Hypoxia regulates FGFR3 expression via HIF-1alpha and miR-100 and contributes to cell survival in non-muscle invasive bladder cancer. Br J Cancer 2013;109:50-59.

49 Oliveira JC, Brassesco MS, Morales AG, Pezuk JA, Fedatto PF, da Silva GN, Scrideli CA, Tone LG: MicroRNA-100 acts as a tumor suppressor in human bladder carcinoma 5637 cells. Asian Pac J Cancer Prev 2011;12:3001-3004.

50 Xu C, Zeng Q, Xu W, Jiao L, Chen Y, Zhang Z, Wu C, Jin T, Pan A, Wei R, Yang B, Sun Y: miRNA-100 inhibits human bladder urothelial carcinogenesis by directly targeting mTOR. Mol Cancer Ther 2013;12:207-219.

51 Wang S, Xue S, Dai Y, Yang J, Chen Z, Fang X, Zhou W, Wu W, Li Q: Reduced expression of microRNA-100 confers unfavorable prognosis in patients with bladder cancer. Diagn Pathol 2012;7:159.

52 Dip N, Reis ST, Timoszczuk LS, Viana NI, Piantino CB, Morais DR, Moura CM, Abe DK, Silva IA, Srougi M, Dall'Oglio MF, Leite KR: Stage, grade and behavior of bladder urothelial carcinoma defined by the microRNA expression profile. J Urol 2012;188:1951-1956.

53 Dip N, Reis ST, Abe DK, Viana NI, Morais DR, Moura CM, Katz B, Silva IA, Srougi M, Leite KR: Micro RNA expression and prognosis in low-grade non-invasive urothelial carcinoma. Int Braz J Urol 2014;40:644649.

54 Morais DR, Reis ST, Viana N, Piantino CB, Massoco C, Moura C, Dip N, Silva IA, Srougi M, Leite KR: The involvement of miR-100 in bladder urothelial carcinogenesis changing the expression levels of mRNA and proteins of genes related to cell proliferation, survival, apoptosis and chromosomal stability. Cancer Cell Int 2014;14:119.

55 Catto JW, Miah S, Owen HC, Bryant H, Myers K, Dudziec E, Larré S, Milo M, Rehman I, Rosario DJ, Martino ED, Knowles MA, Meuth M, Harris AL, Hamdy FC: Distinct microRNA alterations characterize high and low grade bladder cancer. Cancer Res 2009;69:8472-8481. 


\section{Cellular Physiology Cell Physiol Biochem 2015;37:2143-2159 \begin{tabular}{l|l|l}
\hline DOI: 10.1159/000438572 & 2015 The Author(s). Published by S. Karger AG, Basel
\end{tabular} Published online: November 26, 2015 www.karger.com/cpb}

Li et al.: MiR-100: A Potential Therapeutic Target for Human Cancers

56 Chen Y, Zhang L, Hao Q: Candidate microRNA biomarkers in human epithelial ovarian cancer: systematic review profiling studies and experimental validation. Cancer Cell Int 2013;13:86.

57 Gadducci A, Sergiampietri C, Lanfredini N, Guiggi I: Micro-RNAs and ovarian cancer: the state of art and perspectives of clinical research. Gynecol Endocrinol 2014;30:266-271.

58 Nagaraja AK, Creighton CJ, Yu Z, Zhu H, Gunaratne PH, Reid JG, Olokpa E, Itamochi H, Ueno NT, Hawkins SM, Anderson ML, Matzuk MM: A link between mir-100 and FRAP1/mTOR in clear cell ovarian cancer. Mol Endocrinol 2010;24:447-463.

59 Nam EJ, Yoon H, Kim SW, Kim H, Kim YT, Kim JH, Kim JW, Kim S: MicroRNA expression profiles in serous ovarian carcinoma. Clin Cancer Res 2008;14:2690-2695.

60 Peng DX, Luo M, Qiu LW, He YL, Wang XF: Prognostic implications of microRNA-100 and its functional roles in human epithelial ovarian cancer. Oncol Rep 2012;27:1238-1244.

61 Torres A, Torres K, Pesci A, Ceccaroni M, Paszkowski T, Cassandrini P, Zamboni G, Maciejewski R: Deregulation of miR-100, miR-99a and miR-199b in tissues and plasma coexists with increased expression of mTOR kinase in endometrioid endometrial carcinoma. BMC Cancer 2012;12:369.

62 Li BH, Zhou JS, Ye F, Cheng XD, Zhou CY, Lu WG, Xie X: Reduced miR-100 expression in cervical cancer and precursors and its carcinogenic effect through targeting PLK1 protein. Eur J Cancer 2011;47:2166-2174.

63 Wilting SM, Snijders PJ, Verlaat W, Jaspers A, van de Wiel MA, van Wieringen WN, Meijer GA, Kenter GG, Yi Y, le Sage C, Agami R, Meijer CJ, Steenbergen RD: Altered microRNA expression associated with chromosomal changes contributes to cervical carcinogenesis. Oncogene 2013;32:106-116.

64 Huang L, Lin JX, Yu YH, Zhang MY, Wang HY, Zheng M: Downregulation of six microRNAs is associated with advanced stage, lymph node metastasis and poor prognosis in small cell carcinoma of the cervix. PLoS One 2012;7:e33762.

65 Giangreco AA, Vaishnav A, Wagner D, Finelli A, Fleshner N, Van der Kwast T, Vieth R, Nonn L: Tumor suppressor microRNAs, miR-100 and -125b, are regulated by 1,25-dihydroxyvitamin D in primary prostate cells and in patient tissue. Cancer Prev Res (Phila) 2013;6:483-494.

66 Leite KR, Morais DR, Reis ST, Viana N, Moura C, Florez MG, Silva IA, Dip N, Srougi M: MicroRNA 100: a context dependent miRNA in prostate cancer. Clinics (Sao Paulo) 2013;68:797-802.

67 Wang M, Ren D, Guo W, Wang Z, Huang S, Du H, Song L, Peng X: Loss of miR-100 enhances migration, invasion, epithelial-mesenchymal transition and stemness properties in prostate cancer cells through targeting Argonaute 2. Int J Oncol 2014;45:362-372.

68 Leite KR, Sousa-Canavez JM, Reis ST, Tomiyama AH, Camara-Lopes LH, Sanudo A, Antunes AA, Srougi M: Change in expression of miR-let7c, miR-100, and miR-218 from high grade localized prostate cancer to metastasis. Urol Oncol 2011;29:265-269.

69 Leite KR, Tomiyama A, Reis ST, Sousa-Canavez JM, Sanudo A, Dall'Oglio MF, Camara-Lopes LH, Srougi M: MicroRNA-100 expression is independently related to biochemical recurrence of prostate cancer. J Urol 2011;185:1118-1122.

70 Leite KR, Tomiyama A, Reis ST, Sousa-Canavez JM, Sanudo A, Camara-Lopes LH, Srougi M: MicroRNA expression profiles in the progression of prostate cancer--from high-grade prostate intraepithelial neoplasia to metastasis. Urol Oncol 2013;31:796-801.

71 Chen P, Xi Q, Wang Q, Wei P: Downregulation of microRNA-100 correlates with tumor progression and poor prognosis in colorectal cancer. Med Oncol 2014;31:235.

72 Peng H, Luo J, Hao H, Hu J, Xie SK, Ren D, Rao B: MicroRNA-100 regulates SW620 colorectal cancer cell proliferation and invasion by targeting RAP1B. Oncol Rep 2014;31:2055-2062.

73 Yang XD, Xu XH, Zhang SY, Wu Y, Xing CG, Ru G, Xu HT, Cao JP: Role of miR-100 in the radioresistance of colorectal cancer cells. Am J Cancer Res 2015;5:545-559.

74 Zhu Z, Wang CP, Zhang YF, Nie L: MicroRNA-100 resensitizes resistant chondrosarcoma cells to cisplatin through direct targeting of mTOR. Asian Pac J Cancer Prev 2014;15:917-923.

75 Huang J, Gao K, Lin J, Wang Q: MicroRNA-100 inhibits osteosarcoma cell proliferation by targeting Cyr61. Tumour Biol 2014;35:1095-1100.

76 Bi Y, Jing Y, Cao Y: Overexpression of miR-100 inhibits growth of osteosarcoma through FGFR3. Tumour Biol DOI:10.1007/s13277-015-3581-1.

77 Alrfaei BM, Vemuganti R, Kuo JS: microRNA-100 targets SMRT/NCOR2, reduces proliferation, and improves survival in glioblastoma animal models. PLoS One 2013;8:e80865. 


\section{Cellular Physiology Cell Physiol Biochem 2015;37:2143-2159

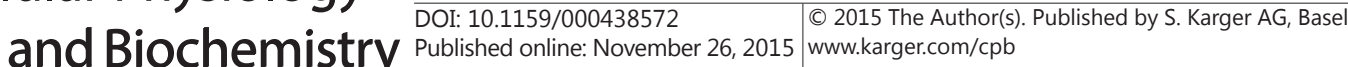 \\ Li et al.: MiR-100: A Potential Therapeutic Target for Human Cancers}

78 Akbari Moqadam F, Lange-Turenhout EA, Aries IM, Pieters R, den Boer ML: MiR-125b, miR-100 and miR99a co-regulate vincristine resistance in childhood acute lymphoblastic leukemia. Leuk Res 2013;37:13151321.

79 de Oliveira JC, Scrideli CA, Brassesco MS, Morales AG, Pezuk JA, Queiroz Rde P, Yunes JA, Brandalise SR, Tone LG: Differential miRNA expression in childhood acute lymphoblastic leukemia and association with clinical and biological features. Leuk Res 2012;36:293-298.

80 Li XJ, Luo XQ Han BW, Duan FT, Wei PP, Chen YQ: MicroRNA-100/99a, deregulated in acute lymphoblastic leukaemia, suppress proliferation and promote apoptosis by regulating the FKBP51 and IGF1R/mTOR signalling pathways. Br J Cancer 2013;109:2189-2198.

81 Schotte D, De Menezes RX, Akbari Moqadam F, Khankahdani LM, Lange-Turenhout E, Chen C, Pieters R, Den Boer ML: MicroRNA characterize genetic diversity and drug resistance in pediatric acute lymphoblastic leukemia. Haematologica 2011;96:703-711.

82 Xiao F, Bai Y, Chen Z, Li Y, Luo L, Huang J, Yang J, Liao H, Guo L: Downregulation of HOXA1 gene affects small cell lung cancer cell survival and chemoresistance under the regulation of miR-100. Eur J Cancer 2014;50:1541-1554.

83 Wang T, Lv M, Shen S, Zhou S, Wang P, Chen Y, Liu B, Yu L, Hou Y: Cell-free microRNA expression profiles in malignant effusion associated with patient survival in non-small cell lung cancer. PLoS One 2012;7:e43268.

84 Zhang YK, Zhu WY, He JY, Chen DD, Huang YY, Le HB, Liu XG: miRNAs expression profiling to distinguish lung squamous-cell carcinoma from adenocarcinoma subtypes. J Cancer Res Clin Oncol 2012;138:16411650.

85 Ueda T, Volinia S, Okumura H, Shimizu M, Taccioli C, Rossi S, Alder H, Liu CG, Oue N, Yasui W, Yoshida K, Sasaki H, Nomura S, Seto Y, Kaminishi M, Calin GA, Croce CM: Relation between microRNA expression and progression and prognosis of gastric cancer: a microRNA expression analysis. Lancet Oncol 2010;11:136146.

86 Wang Y, Gao Y, Shi W, Zhai D, Rao Q, Jia X, Liu J, Jiao X, Du Z: Profiles of differential expression of circulating microRNAs in hepatitis B virus-positive small hepatocellular carcinoma. Cancer Biomark 2015;15:177-186.

87 Huang JS, Egger ME, Grizzle WE, McNally LR: MicroRNA-100 regulates IGF1-receptor expression in metastatic pancreatic cancer cells. Biotech Histochem 2013;88:397-402.

88 Panarelli NC, Chen YT, Zhou XK, Kitabayashi N, Yantiss RK: MicroRNA expression aids the preoperative diagnosis of pancreatic ductal adenocarcinoma. Pancreas 2012;41:685-690.

89 LaConti JJ, Shivapurkar N, Preet A, Deslattes Mays A, Peran I, Kim SE, Marshall JL, Riegel AT, Wellstein A: Tissue and serum microRNAs in the Kras(G12D) transgenic animal model and in patients with pancreatic cancer. PLoS One 2011;6:e20687.

90 Wang G, Chen L, Meng J, Chen M, Zhuang L, Zhang L: Overexpression of microRNA-100 predicts an unfavorable prognosis in renal cell carcinoma. Int Urol Nephrol 2013;45:373-379.

91 Bai J, Guo A, Hong Z, Kuai W: Upregulation of microRNA-100 predicts poor prognosis in patients with pediatric acute myeloid leukemia. Onco Targets Ther 2012;5:213-219.

92 Rucker FG, Russ AC, Cocciardi S, Kett H, Schlenk RF, Botzenhardt U, Langer C, Krauter J, Frohling S, Schlegelberger B, Ganser A, Lichter P, Zenz T, Dohner H, Dohner K, Bullinger L: Altered miRNA and gene expression in acute myeloid leukemia with complex karyotype identify networks of prognostic relevance. Leukemia 2013;27:353-361.

93 Zhang H, Luo XQ Zhang P, Huang LB, Zheng YS, Wu J, Zhou H, Qu LH, Xu L, Chen YQ: MicroRNA patterns associated with clinical prognostic parameters and CNS relapse prediction in pediatric acute leukemia. PLoS One 2009;4:e7826.

94 Zheng YS, Zhang H, Zhang XJ, Feng DD, Luo XQ Zeng CW, Lin KY, Zhou H, Qu LH, Zhang P, Chen YQ: MiR-100 regulates cell differentiation and survival by targeting RBSP3, a phosphatase-like tumor suppressor in acute myeloid leukemia. Oncogene 2012;31:80-92.

95 Mabuchi S, Kawase C, Altomare DA, Morishige K, Sawada K, Hayashi M, Tsujimoto M, Yamoto M, KleinSzanto AJ, Schilder RJ, Ohmichi M, Testa JR, Kimura T: mTOR is a Promising Therapeutic Target Both in Cisplatin-Sensitive and Cisplatin-Resistant Clear Cell Carcinoma of the Ovary. Clin Cancer Res 2009;15:5404-5413.

96 Bhushan L, Kandpal RP: EphB6 receptor modulates micro RNA profile of breast carcinoma cells. PLoS One 2011;6:e22484. 


\section{Cellular Physiology Cell Physiol Biochem 2015;37:2143-2159

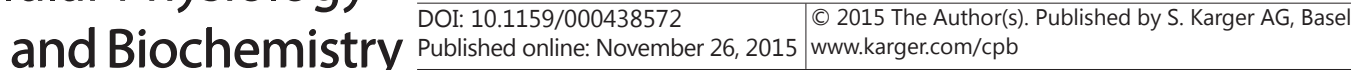 \\ Li et al.: MiR-100: A Potential Therapeutic Target for Human Cancers}

97 Vivanco I, Sawyers CL: The phosphatidylinositol 3-Kinase AKT pathway in human cancer. Nat Rev Cancer 2002;2:489-501.

98 Laplante M, Sabatini DM: mTOR signaling in growth control and disease. Cell 2012;149:274-293.

99 Xu H, Liu X, Zhao J: Down-regulation of miR-3928 promoted osteosarcoma growth. Cell Physiol Biochem 2014;33:1547-1556.

100 Lee KB, Byun HJ, Park SH, Park CY, Lee SH, Rho SB: CYR61 controls p53 and NF-kappaB expression through PI3K/Akt/mTOR pathways in carboplatin-induced ovarian cancer cells. Cancer Lett 2012;315:86-95.

101 Li H, Li Y, Liu D, Sun H, Liu J: miR-224 is critical for celastrol-induced inhibition of migration and invasion of hepatocellular carcinoma cells. Cell Physiol Biochem 2013;32:448-458.

102 Pan W, Wang H, Jianwei R, Ye Z: MicroRNA-27a promotes proliferation, migration and invasion by targeting MAP2K4 in human osteosarcoma cells. Cell Physiol Biochem 2014;33:402-412.

103 Fulda S, Vucic D: Targeting IAP proteins for therapeutic intervention in cancer. Nat Rev Drug Discov 2012;11:109-124.

104 Du W, Pan Z, Chen X, Wang L, Zhang Y, Li S, Liang H, Xu C, Zhang Y, Wu Y, Shan H, Lu Y: By targeting Stat3 microRNA-17-5p promotes cardiomyocyte apoptosis in response to ischemia followed by reperfusion. Cell Physiol Biochem 2014;34:955-965.

105 Wang J, Yang B, Han L, Li X, Tao H, Zhang S, Hu Y: Demethylation of miR-9-3 and miR-193a genes suppresses proliferation and promotes apoptosis in non-small cell lung cancer cell lines. Cell Physiol Biochem 2013;32:1707-1719.

106 Liang H, Li X, Wang L, Yu S, Xu Z, Gu Y, Pan Z, Li T, Hu M, Cui H, Liu X, Zhang Y, Xu C, Guo R, Lu Y, Yang B, Shan H: MicroRNAs contribute to promyelocyte apoptosis in As203-treated APL cells. Cell Physiol Biochem 2013;32:1818-1829.

107 Baserga R, Peruzzi F, Reiss K: The IGF-1 receptor in cancer biology. Int J Cancer 2003;107:873-877.

108 Li L, Lou Z, Wang L: The role of FKBP5 in cancer aetiology and chemoresistance. Br J Cancer 2011;104:1923.

109 Jiang W, Cazacu S, Xiang C, Zenklusen JC, Fine HA, Berens M, Armstrong B, Brodie C, Mikkelsen T: FK506 binding protein mediates glioma cell growth and sensitivity to rapamycin treatment by regulating NFkappaB signaling pathway. Neoplasia 2008;10:235-243.

110 Romano S, Sorrentino A, Di Pace AL, Nappo G, Mercogliano C, Romano MF: The emerging role of large immunophilin FK506 binding protein 51 in cancer. Curr Med Chem 2011;18:5424-5429.

111 Raman K, Kuberan B: Chemical Tumor Biology of Heparan Sulfate Proteoglycans. Curr Chem Biol 2010;4:20-31.

112 Han ZB, Yang Z, Chi Y, Zhang L, Wang Y, Ji Y, Wang J, Zhao H, Han ZC: MicroRNA-124 suppresses breast cancer cell growth and motility by targeting CD151. Cell Physiol Biochem 2013;31:823-832.

113 Yang X, Ni W, Lei K: miR-200b suppresses cell growth, migration and invasion by targeting Notch1 in nasopharyngeal carcinoma. Cell Physiol Biochem 2013;32:1288-1298.

114 Ghose J, Director NP: Transcriptional regulation of microRNA-100, -146a, and -150 genes by p53 and NFkappaB p65/RelA in mouse striatal STHdh/ Hdh cells and human cervical carcinoma HeLa cells. RNA Biol 2015;12:457-477.

115 McInnes C, Wyatt MD: PLK1 as an oncology target: current status and future potential. Drug Discov Today 2011;16:619-625.

116 Wang ZX, Xue D, Liu ZL, Lu BB, Bian HB, Pan X, Yin YM: Overexpression of polo-like kinase 1 and its clinical significance in human non-small cell lung cancer. Int J Biochem Cell Biol 2012;44:200-210.

117 Archambault V, Glover DM: Polo-like kinases: conservation and divergence in their functions and regulation. Nat Rev Mol Cell Biol 2009;10:265-275.

118 Valastyan S, Weinberg RA: Tumor metastasis: molecular insights and evolving paradigms. Cell 2011;147:275-292.

119 Zhou X, Xia Y, Su J, Zhang G: Down-regulation of miR-141 induced by helicobacter pylori promotes the invasion of gastric cancer by targeting STAT4. Cell Physiol Biochem 2014;33:1003-1012.

120 Sreekumar R, Sayan BS, Mirnezami AH, Sayan AE: MicroRNA Control of Invasion and Metastasis Pathways. Front Genet 2011;2:58.

121 Luo D, Wilson JM, Harvel N, Liu J, Pei L, Huang S, Hawthorn L, Shi H: A systematic evaluation of miRNA:mRNA interactions involved in the migration and invasion of breast cancer cells. J Transl Med 2013;11:57. 


\section{Cellular Physiology Cell Physiol Biochem 2015;37:2143-2159 \begin{tabular}{l|l|l} 
DOI: 10.1159/000438572 & $\begin{array}{l}\text { C } 2015 \text { The Author(s). Published by S. Karger AG, Basel } \\
\text { www.karger.com/cpb }\end{array}$ \\
\hline
\end{tabular} \\ Li et al.: MiR-100: A Potential Therapeutic Target for Human Cancers}

122 Li W, Jiang G, Zhou J, Wang H, Gong Z, Zhang Z, Min K, Zhu H, Tan Y: Down-regulation of miR-140 induces EMT and promotes invasion by targeting Slug in esophageal cancer. Cell Physiol Biochem 2014;34:14661476.

123 Lee TK, Poon RT, Yuen AP, Man K, Yang ZF, Guan XY, Fan ST: Rac activation is associated with hepatocellular carcinoma metastasis by up-regulation of vascular endothelial growth factor expression. Clin Cancer Res 2006;12:5082-5089.

124 Winter-Vann AM, Casey PJ: Post-prenylation-processing enzymes as new targets in oncogenesis. Nat Rev Cancer 2005;5:405-412.

125 Kandpal RP: Tyrosine kinase-deficient EphB6 receptor-dependent alterations in proteomic profiles of invasive breast carcinoma cells as determined by difference gel electrophoresis. Cancer Genomics Proteomics 2010;7:253-260.

126 Fox BP, Kandpal RP: Invasiveness of breast carcinoma cells and transcript profile: Eph receptors and ephrin ligands as molecular markers of potential diagnostic and prognostic application. Biochem Biophys Res Commun 2004;318:882-892.

127 Qiu YH, Wei YP, Shen NJ, Wang ZC, Kan T, Yu WL, Yi B, Zhang YJ: miR-204 inhibits epithelial to mesenchymal transition by targeting slug in intrahepatic cholangiocarcinoma cells. Cell Physiol Biochem 2013;32:13311341.

128 Brabletz T, Jung A, Spaderna S, Hlubek F, Kirchner T: Opinion: migrating cancer stem cells - an integrated concept of malignant tumour progression. Nat Rev Cancer 2005;5:744-749.

129 Thiery JP, Acloque H, Huang RY, Nieto MA: Epithelial-mesenchymal transitions in development and disease. Cell 2009;139:871-890.

130 Shimamura T, Imoto S, Shimada Y, Hosono Y, Niida A, Nagasaki M, Yamaguchi R, Takahashi T, Miyano S: A novel network profiling analysis reveals system changes in epithelial-mesenchymal transition. PLoS One 2011;6:e20804.

131 Marson A, Levine SS, Cole MF, Frampton GM, Brambrink T, Johnstone S, Guenther MG, Johnston WK, Wernig M, Newman J, Calabrese JM, Dennis LM, Volkert TL, Gupta S, Love J, Hannett N, Sharp PA, Bartel DP, Jaenisch $\mathrm{R}$, Young RA: Connecting microRNA genes to the core transcriptional regulatory circuitry of embryonic stem cells. Cell 2008;134:521-533.

132 Kanellopoulou C, Muljo SA, Kung AL, Ganesan S, Drapkin R, Jenuwein T, Livingston DM, Rajewsky K: Dicerdeficient mouse embryonic stem cells are defective in differentiation and centromeric silencing. Genes Dev 2005;19:489-501.

133 Polytarchou C, Iliopoulos D, Struhl K: An integrated transcriptional regulatory circuit that reinforces the breast cancer stem cell state. Proc Natl Acad Sci U S A 2012;109:14470-14475.

134 Wan L, Zhu L, Xu J, Lu B, Yang Y, Liu F, Wang Z: MicroRNA-409-3p functions as a tumor suppressor in human lung adenocarcinoma by targeting c-Met. Cell Physiol Biochem 2014;34:1273-1290.

135 Yuan Q Gao W, Liu B, Ye W: Upregulation of miR-184 enhances the malignant biological behavior of human glioma cell line A172 by targeting FIH-1. Cell Physiol Biochem 2014;34:1125-1136.

136 Mahn R, Heukamp LC, Rogenhofer S, von Ruecker A, Muller SC, Ellinger J: Circulating microRNAs (miRNA) in serum of patients with prostate cancer. Urology 2011;77:1265.e1269-1216.

137 Ludwig N, Nourkami-Tutdibi N, Backes C, Lenhof HP, Graf N, Keller A, Meese E: Circulating serum miRNAs as potential biomarkers for nephroblastoma. Pediatr Blood Cancer 2015;62:1360-1367.

138 He Y, Meng C, Shao Z, Wang H, Yang S: MiR-23a functions as a tumor suppressor in osteosarcoma. Cell Physiol Biochem 2014;34:1485-1496.

139 Xu G, Wang J, Jia Y, Shen F, Han W, Kang Y: MiR-142-3p functions as a potential tumor suppressor in human osteosarcoma by targeting HMGA1. Cell Physiol Biochem 2014;33:1329-1339.

140 Zhu Y, Xia Y, Niu H, Chen Y: MiR-16 induced the suppression of cell apoptosis while promote proliferation in esophageal squamous cell carcinoma. Cell Physiol Biochem 2014;33:1340-1348.

141 Long W, Zhao C, Ji C, Ding H, Cui Y, Guo X, Shen R, Liu J: Characterization of serum microRNAs profile of PCOS and identification of novel non-invasive biomarkers. Cell Physiol Biochem 2014;33:1304-1315.

142 Zhou J, Lu S, Yang S, Chen H, Shi H, Miao M, Jiao B: MicroRNA-127 post-transcriptionally downregulates Sept7 and suppresses cell growth in hepatocellular carcinoma cells. Cell Physiol Biochem 2014;33:15371546.

143 Simonson B, Das S: MicroRNA Therapeutics: the Next Magic Bullet? Mini Rev Med Chem 2015;15:467-474. 


\section{Cellular Physiology Cell Physiol Biochem 2015;37:2143-2159

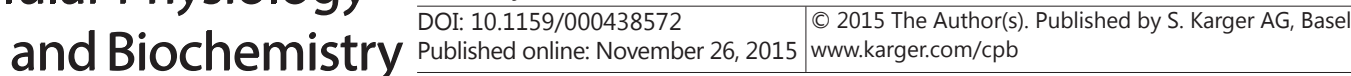

Li et al.: MiR-100: A Potential Therapeutic Target for Human Cancers

144 Garzon R, Marcucci G, Croce CM: Targeting microRNAs in cancer: rationale, strategies and challenges. Nat Rev Drug Discov 2010;9:775-789.

145 Melo SA, Kalluri R: Molecular pathways: microRNAs as cancer therapeutics. Clin Cancer Res 2012;18:42344239.

146 Hu X, Zhang F, Liu XR, Wu YT, Ni YM: Efficacy and potential microRNA mechanism for computed tomography-guided percutaneous radiofrequency ablation of primary lung cancer and lung metastasis from liver cancer. Cell Physiol Biochem 2014;33:1261-1271.

147 Wang L, Li L, Guo R, Li X, Lu Y, Guan X, Gitau SC, Wang L, Xu C, Yang B, Shan H: miR-101 promotes breast cancer cell apoptosis by targeting Janus kinase 2. Cell Physiol Biochem 2014;34:413-422.

148 Li B, Sun M, Gao F, Liu W, Yang Y, Liu H, Cheng Y, Liu C, Cai J: Up-regulated expression of miR-23a/b targeted the pro-apoptotic Fas in radiation-induced thymic lymphoma. Cell Physiol Biochem 2013;32:1729-1740.

149 Zhang J, Zhang H, Chen L, Sun da W, Mao C, Chen W, Wu JZ, Zhong SL, Zhao JH, Tang JH: beta-elemene reverses chemoresistance of breast cancer via regulating MDR-related microRNA expression. Cell Physiol Biochem 2014;34:2027-2037.

150 Zhu Y, Wu J, Li S, Ma R, Cao H, Ji M, Jing C, Tang J: The function role of miR-181a in chemosensitivity to adriamycin by targeting Bcl-2 in low-invasive breast cancer cells. Cell Physiol Biochem 2013;32:12251237.

151 Zhang L, Qian J, Qiang Y, Huang H, Wang C, Li D, Xu B: Down-regulation of miR-4500 promoted non-small cell lung cancer growth. Cell Physiol Biochem 2014, 34:1166-1174.

152 Lobert S, Jefferson B, Morris K: Regulation of beta-tubulin isotypes by micro-RNA 100 in MCF7 breast cancer cells. Cytoskeleton (Hoboken) 2011;68:355-362.

153 Ng WL, Yan D, Zhang X, Mo YY, Wang Y: Over-expression of miR-100 is responsible for the low-expression of ATM in the human glioma cell line: M059J. DNA Repair (Amst) 2010;9:1170-1175. 